\title{
A structural model of job resources, organisational and individual strengths use and work engagement
}

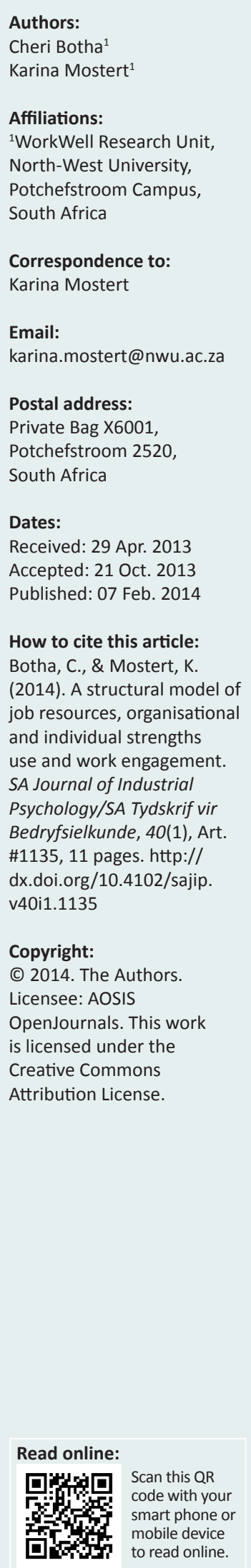

Orientation: Organisations will not be able to maintain a competitive advantage by merely focusing on the development of their employees' weaknesses. Employees should also be provided with sufficient job resources and opportunities to develop and use their strengths, as this could lead to work engagement.

Research purpose: To test a structural model of job resources, perceived organisational support for strengths use, proactive behaviour towards strengths use and work engagement amongst South African employees.

Motivation for the study: To gain more knowledge and a better understanding of the outcomes of following an organisational and individual strength-based approach focused on the use of strengths within the South African context.

Research approach, design and method: A quantitative approach with cross-sectional research design was used. An availability sample $(N=401)$ of employees from various occupational groups in South Africa was used. Structural equation modelling was used to test the model.

Main findings: The results indicated that perceived organisational support for strengths use and employees' proactive behaviour towards strengths use were strongly and positively associated with work engagement in the structural model.

Practical/managerial implications: Knowledge of using strengths from an organisational and individual perspective could assist organisations in gaining a better understanding of the relationship with work engagement.

Contribution/value-add: This study adds to the limited research on using strengths from both an organisational and individual perspective and possible outcomes within the South African context.

\section{Introduction}

The most valuable asset of any organisation is its human capital (Shults, 2008). It is therefore of the utmost importance to develop employees in order to optimise performance towards a competitive advantage. However, in order to increase performance, many organisations are following a 'deficiency approach', that is developing their employees' weaknesses (Buckingham \& Clifton, 2001). According to Clifton and Harter (2003), an organisation that follows a deficiency approach focuses on employees who do not function well by providing them with training around their weak points or areas of underdevelopment.

At the turn of the century, a paradigm shift occurred, and the science of positive psychology emerged (Kristjánsson, 2010; Seligman \& Csikszentmihalyi, 2000). This positive approach to psychology is concerned with the well-being and the optimal functioning of the individual (Duckworth, Steen \& Seligman, 2005). The development of individuals' talents into strengths is at the forefront of the positive psychology movement (Jimerson, Sharkey, Nyborg \& Furlong, 2004). The development of the positive psychology movement also gained popularity, with organisational researchers focusing on its implications in the work environment (Luthans \& Youssef, 2007). In this respect, a number of domains and approaches have recently emerged (Luthans \& Youssef, 2007). One of these new domains for application in the work context is called 'positive organisational behaviour' (Luthans, 2002a; Luthans \& Youssef, 2007). According to Luthans (2002b, p. 59), positive organisational behaviour can be defined as the study and application of positively oriented human resource strengths and psychological capacities that can be measured, developed, and effectively managed for performance improvement in today's workplace'. Therefore, with reference to the definition of positive organisational behaviour and the basis of positive psychology, there seems to be a link between positive organisational behaviour and a focus on strengths.

Research has indicated that when people develop and use their strengths, it leads to positive psychological and behavioural outcomes (Biswas-Diener, Kashdan \& Minhas, 2011; Linley, 
Nielsen, Wood, Gillett \& Biswas-Diener, 2010). They are happier, have fewer feelings of depression (Seligman, Steen, Parks \& Peterson, 2005) and are more productive (Clifton \& Harter, 2003). These findings also correlate with the 'happyproductive' thesis, which indicates that happy employees are more productive (Zelenski, Murphy \& Jenkins, 2008). Studies done by Govindji and Linley (2007), and Linley et al. (2010) have indicated that when applying their strengths, people have higher levels of energy and vitality. When employees indicated that they had the opportunity to develop and use their strengths, organisations demonstrated higher customer loyalty and lower employee turnover (Clifton \& Harter, 2003).

The use of strengths is important both on an organisational and an individual level (Biswas-Diener et al., 2011; Els, Mostert, Van Woerkom, Rothmann \& Bakker, in press). According to Linley and Harrington $(2005,2006)$, individuals have a natural tendency to grow and develop their potential and if they find themselves in an environment that supports their specific need for development, they will flourish. Research has indicated that when employees' strengths are implemented, it adds to their goal attainment, and enhances their self-esteem and well-being, which results in them feeling happier and more fulfilled (Govindji \& Linley, 2007; Linley et al., 2010). These positive emotions result in their functioning at a higher level (Fredrickson, 2004), which, in the long term, contributes to the well-being of the organisation (Liehmann, 2009).

Strengths use can be instilled from an individual (employee) and an organisational perspective (Clifton \& Harter, 2003). It is therefore important for employees to perceive their organisations as supportive of the use of their strengths. By supporting the use of their employees' strengths, organisations can assist them to reach their full potential, which is beneficial to the family, the organisation and to society (Linley \& Harrington, 2006). However, it is equally important for employees themselves to display proactive behaviour towards using their own strengths (Els et al., in press), which may be associated with enhanced experiences of positive emotions and personal well-being (Govindji \& Linley, 2007; Proctor, Maltby \& Linley, 2011).

\section{Research purpose and objectives}

It is important to focus equally on both developing and using strengths. However, although previous research has consistently showed that there is an association between the use of strengths and higher performance, better goal progress, greater well-being and vitality (Govindji \& Linley, 2007; Linley et al., 2010; Wood, Linley, Maltby, Kashdan \& Hurling, 2011), the majority of research focuses on the consequences for well-being of having strengths, whilst very few studies investigate whether using strengths also leads to beneficial outcomes. Possessing more of a strength compared to other people may be related to positive outcomes, but it is the unblocked use of a certain strength that would most probably be associated with the most benefits (Wood et al., 2011).
Furthermore, only two studies could be found that focused on the relationship between strengths use and well-being (cf. Govindji \& Linley, 2007; Wood et al., 2011). However, they measured individual strengths use and well-being in very general terms, applicable to a variety of settings and not specifically in the workplace. Within the organisational context, it is important to investigate the relationship between the use of strengths, both from an organisational and an individual perspective, and work engagement (an indicator of work-related well-being). The central research question of this study is therefore: What is the relationship between perceived organisational support for strengths use (POSSU) and employees' proactive behaviour towards strengths use (PBSU), whilst controlling for job resources, and work engagement?

The limited research on the relationship of strengths use to positive outcomes is surprising, since the underlying assumption of most theories on how strengths work to improve well-being is based on the application of strengths in personal and organisational settings (Harter, Schmidt \& Hayes, 2002; Seligman, Rashid \& Parks, 2006). The objectives of this study were therefore to develop and test a structural model and to test whether perceived organisational support for strengths use and individual proactive behaviour towards strengths use, in addition to job resources, are significantly related to work engagement.

This research extends the focus on strengths use by applying it specifically within the organisational context through an empirical consideration of how strengths use (on both organisational and individual levels) may influence work engagement. This could help the organisation to gain a better understanding of whether or not the employees feel that their talents are being used. The organisation can then work in collaboration with its employees to use their strengths.

Next, a concise literature review will be provided. Research hypotheses will follow from the literature review. This will be followed by a description of the method and presentation of the results. Finally, a brief discussion and interpretation of the results will follow, as well as the limitations and recommendations.

\section{Literature review}

\section{The job demands-resources model and work engagement}

The job demands-resources (JD-R) model can be used to explain how job resources affectemployees' work engagement levels. The JD-R model (Bakker \& Demerouti, 2007; Bakker, Demerouti, Taris, Schaufeli \& Schreurs, 2003; Demerouti \& Bakker, 2011) recognises that every occupation has its own specific risk factors that are associated with job-related stress. According to Demerouti and Bakker (2011), these factors can be categorised into two groups, namely job demands and job resources. The above model can be applied in various occupational settings, irrespective of the particular demands and resources involved (Demerouti \& Bakker, 2011). Job demands can be defined as the physical, psychological, social 
and organisational aspects of a job that require sustained physical or psychological (cognitive and emotional) efforts, and are associated with physiological or psychological costs (Bakker, Demerouti \& Verbeke, 2004). A job resource is the physical, psychological, social or organisational aspect of an individual's job that decreases the job demands and the physiological and psychological costs that are associated with it; therefore, a job resource helps individuals to attain their goals and encourages their personal growth, learning and development (Demerouti \& Bakker, 2011; Schaufeli \& Bakker, 2004).

Schaufeli and Bakker (2004) define work engagement as a positive, fulfilling, work-related state of mind that is characterised by vigour, dedication and absorption (see also Schaufeli, Salanova, González-Romá \& Bakker, 2002). According to Schaufeli et al. (2002), vigour refers to the consistent high energy levels and mental resilience that individuals experience whilst they work. Dedication implies that individuals are strongly involved in their work, and experience feelings of significance, enthusiasm and challenge. Absorption denotes that the individuals are fully concentrating on and happily engrossed in their work, such that time passes quickly and it is difficult to detach them from their work. These engagement dimensions are seen as the opposite of the burnout scales, except for absorption, which is not considered the opposite of professional inefficacy (Schaufeli \& Bakker, 2004). Absorption is also considered to be a relevant aspect of work engagement, but plays a less central role; it can rather be seen as a consequence of engagement (Schaufeli \& Bakker, 2004). Therefore, only the 'core' concepts of engagement, namely vigour and dedication, were used (see Schaufeli \& Bakker, 2004).

It is very important for the employees of any organisation to stay engaged, because of all the positive outcomes of engagement for both the employees and the organisation (Bakker, Hakanen, Demerouti \& Xanthopoulou, 2007). Research has indicated that work engagement contributes to employees experiencing good health, as well as a positive work affect (Demerouti, Bakker, De Jonge, Janssen \& Schaufeli, 2001; Rothbard, 2001). According to Demerouti et al. (2001), employees who are engaged in their work are more committed to the organisation, and they express this positive behaviour by taking personal initiative; they are also motivated to learn (Sonnentag, 2003). A study done by Harter et al. (2002) found that employees' engagement levels have a positive impact on the performance of the organisation's business units (i.e. higher organisational profitability, enhanced productivity, more customer satisfaction and loyalty, a lower employee turnover and improved safety). Therefore, it is crucial for employees to be engaged in their work, because it will help the organisation to attain and to maintain a competitive advantage (Bakker, Schaufeli, Leiter \& Taris, 2008).

Bakker and Demerouti (2007) found that there is a positive relationship between the job resources that are offered by an organisation (for example, support from colleagues and supervisors, feedback on an employee's performance, a variety of skills, autonomy and learning opportunities) and employees' work engagement levels. Indeed, several studies, internationally and in South Africa, have reported positive relationships between job resources and work engagement (Bakker \& Demerouti, 2007; Bakker \& Demerouti, 2008; Mostert, 2006; Mostert, Peeters \& Rost, 2011; Schaufeli \& Bakker, 2004).

Hypothesis 1: Job resources have a significant positive relationship with work engagement.

\section{Perceived organisational support for strengths use and employees' proactive behaviour towards strength use}

To optimally develop and use employees' strengths, organisations need to show support for employees. Eisenberger, Huntington, Hutchison and Sowa (1986) define perceived organisational support as when employees form general beliefs about the extent to which the organisation values their contributions and cares about their well-being. The authors further state that these general beliefs are formed to meet employees' needs for praise and approval from the organisation as well as to infer the organisation's readiness to reward greater efforts to meet organisational goals. When employees perceive the organisation's support and general positive orientation towards them, this may result in employees feeling indebted to strive towards achieving the organisation's goals (Rhoades \& Eisenberger, 2002).

Employees can experience different forms of organisational support, including perceived organisational support for innovation (Henkin \& Holliman, 2009), creativity (Zhou \& George, 2001) and personal development (Hung \& Mondejar, 2001). Against this background, Els et al. (in press) identify an additional form of perceived organisational support, namely perceived organisational support for strengths use, and define it as the extent to which employees perceive their organisation to be supportive of them using their strengths in the workplace.

Proactive behaviour is evident when people take the initiative to improve their current situation or circumstances or when they create new advantageous conditions for themselves, rather than passively adapting to present circumstances (Crant, 2000). Proactivity at work can also be seen as taking initiative (e.g. performing an assignment without specifically being asked to do so) and displaying assertiveness taking charge in general (Crant, 2000; Morrison \& Phelps, 1999). Furthermore, proactive behaviour in the working environment is characterised by self-starting behaviour of an employee aimed at, amongst other things, improving working conditions and developing personal prerequisites to meet work demands, as well as seeking learning opportunities (Frese, Kring, Soose \& Zempel, 1996; Parker, 2000). Proactive behaviour involves personal initiative, which can be defined as 'work behaviour characterised by its self-starting nature, its proactive approach and by being persistent in overcoming 
difficulties that arise in the pursuit of a goal' (Frese \& Fay, 2001, p. 134).

Although there are different types of proactive behaviour that can be found in the literature (e.g. demonstrating initiative, Frese \& Fay, 2001; seeking information, Morrison, 1993; taking charge, Morrison \& Phelps, 1999), Els et al. (in press) argue that another form of proactive behaviour can occur when employees actively look for opportunities to use their strengths within the work context. They define proactive behaviour towards strengths use as employees' self-starting behaviour directed towards using their strengths in the workplace.

\section{The broaden-and-build theory}

According to Linley et al. (2010), little is known about the mechanisms by which strengths use might lead to psychological benefits such as greater well-being. Except for their own study, very few published studies specifically test the underlying mechanisms by which the use of strengths might lead to enhanced well-being. One theoretical framework that might explain the underlying processes of the relationship between POSSU and PBSU with work engagement is the broaden-and-build theory (Fredrickson, 1998, 2001, 2004; Fredrickson \& Losada, 2005).

The broaden-and-build theory of positive emotions explains the psychological mechanisms through which positivity influences human flourishing. According to this theory, positive emotions broaden peoples' momentary thoughtaction repertoires and build their enduring personal resources, such as social connections, better coping strategies and knowledge about the environment. Through the experience of positive emotions, people then transform themselves, becoming more creative, knowledgeable, resilient, socially integrated and healthy (Fredrickson, 1998, 2001, 2004; Fredrickson \& Losada, 2005). By broadening individuals' mindsets and building their psychological resources, positive emotions should also enhance peoples' emotional and physical well-being over time.

Fredrickson and Losada (2005) state that positive emotions or moods change individuals for the better by making them more resilient, socially integrated and effective. Positive emotions may also lead to better performance in more complex jobs because it could enhance creative problem-solving (Estrada, Isen \& Young, 1997; Madjar, Oldham \& Pratt, 2002). Martin, Ward, Achee and Wyer (1993) showed that positive moods predicted persistence when people were told to work until they felt like stopping. The broaden-and-build theory also suggests that positive affect produces future health and wellbeing (Fredrickson, 2001). Indeed, studies by Fredrickson and her colleagues show that positive affect at the initial assessment predicts increases in well-being several weeks later, mainly because people's mindsets were broadened (Fredrickson \& Joiner, 2002) and because their psychological resources were built (Fredrickson, Brown, Cohn, Conway \& Mikels, 2005). The underlying processes described by the broaden-and-build theory motivate our prediction that the use of strengths, which creates positive emotions, is associated with work engagement.

\section{The relationship between POSSU and PBSU and work engagement}

POSSU can be conceptualised as a job resource at the macro or organisational level that can play an extrinsic motivational role (in addition to other job resources) in the sense that a work environment that focuses on and uses its employees' strengths may foster the willingness of the employees to dedicate their efforts and abilities to the work task (Demerouti \& Bakker, 2011; Els et al., in press). Job resources have a positive impact on employees' work engagement (Bakker \& Demerouti, 2007; Xanthopoulou, Bakker, Demerouti \& Schaufeli, 2009). Because POSSU can be seen as a job resource, it seems possible that it will play a fulfilling and motivational role and will provide employees with an additional resource, which, in turn, could be associated with an eagerness to perform their tasks and increase their engagement in their work (Bakker \& Demerouti, 2008).

In a study done by Linley and Harrington (2006), the results indicate that when an organisation focuses on the development of its employees' strengths, the employees are likely to be more engaged, have higher energy levels and be more motivated, which will lead to improved work performance. Other research findings have also indicated a significant relationship between the development of employees' strengths and work engagement levels (BiswasDiener et al., 2011; Harter et al., 2002).

Hypothesis 2: There is a significant positive relationship between perceived organisational support for strengths use and work engagement.

It appears that research has confirmed that the use of strengths by individuals is associated with a wide range of desirable psychological and behavioural outcomes: Seligman $(2002,2011)$ and Littman-Ovadia and Steger (2010) show that positive experiences at work - including job satisfaction, pleasure, engagement and meaning at work - are facilitated when individuals' strengths are applied at work. The use of personal and psychological strengths has been suggested to lead to energising experiences and elevated, sustainable wellbeing (Peterson \& Seligman, 2004). Longitudinal research by Wood et al. (2011) confirms this finding and shows that people who reported a greater use of their strengths develop greater levels of well-being over time - greater strengths use was related to greater self-esteem, vitality, positive affect and lower perceived stress. Within the coaching psychology literature, Govindji and Linley (2007) report that individuals who use their strengths more frequently experience more subjective and psychological well-being, even when controlling for the effects of self-efficacy and self-esteem. In a follow-up study, Proctor, Maltby and Linley (2009) replicated these findings. Harter et al. (2002) found that people who regularly use their strengths are more engaged at work. 
Similarly, Peterson, Stephens, Park, Lee and Seligman (2009) provide initial evidence that strengths are related to work satisfaction. Taken together, it seems likely that employees' PBSU will be positively related to work engagement.

Hypothesis 3: There is a significant positive relationship between individual proactive behaviour towards strengths use and work engagement.

\section{Research design The research approach}

A quantitative approach was followed using a crosssectional design. A cross-sectional method examines numerous people at one point in time (Salkind, 2009). This approach is appropriate for this study due to it being economical and time effective. The study is both descriptive and exploratory. The hypotheses are supported by existing theory from a strength-based approach. The data analysis was done by making use of a correlation approach.

\section{The research method}

\section{Research participants}

For the purpose of this study, a convenience sample of employees from various occupational groups in South Africa was used $(N=401)$. The mean age was 36.82 . The sample consisted of $234(58.4 \%)$ women and $161(40.1 \%)$ men. The two dominant language groups were Afrikaans (35.2\%) and English (24.7\%), whilst $40.1 \%$ were other African languages. Furthermore, 174 (43.4\%) of the sample were White people, $153(38.2 \%)$ Black people, 52 (13.0\%) people of mixed-race, $12(3.0 \%)$ Asian people and 9 people (2.1\%) fell into other racial groups. Of the sample, $166(41.4 \%)$ indicated that they had a Grade 12 certificate and 196 (48.9\%) had a tertiary qualification. The sample spanned various industries within the South African context: automotive $(0.7 \%)$, chemicals $(0.2 \%)$, engineering $(7.2 \%)$, education $(5.2 \%)$, finance $(3.7 \%)$, media $(0.2 \%)$, mining and metals $(23.4 \%)$, nursing $(6.0 \%)$, oil and gas $(0.2 \%)$, police $(0.7 \%)$, retail $(3.7 \%)$, sport $(0.2 \%)$, telecommunications $(1.0 \%)$, tourism, leisure and recreation $(0.2 \%)$, transportation $(1.5 \%)$ and other $(18.0 \%)$. Of the participants, $87(21.7 \%)$ were single without children living at home, $55(13.7 \%)$ were single with children living at home; $63(15.7 \%)$ were married or living with a partner, without children living at home, $152(37.9 \%)$ were married, or living with a partner, with children living at home and 25 (6.2\%) were living with their parents.

\section{Measuring instruments}

Biographical questionnaire: A biographical questionnaire was utilised to determine the biographical characteristics of the participants. Characteristics such as year of birth, gender, home language, race, level of education, household status (marital and parental status), years working in the organisation and current position were measured by means of this questionnaire.

Job resources: Five resources, namely autonomy, relationship with colleagues, relationship with supervisors, information and participation, were measured with the questionnaire on the experience and assessment of work (Van Veldhoven, Meijman, Broersen \& Fortuin, 1997) for the purpose of this study. All the items were scored on a four-point frequencyrating scale ranging from 1 (always) to 4 (never). Autonomy was measured by means of five items: relationship with colleagues was measured by means of three items, relationship with the supervisors was measured by means of four items, information was measured by means of four items and participation was measured by means of four items. The validity and reliability of the questionnaire have been proven on numerous occasions (Van Veldhoven, Meijman, Broersen \& Fortuin, 2002). Van Veldhoven et al. (2002) report sufficient Cronbach's alpha coefficients for autonomy $(\alpha=0.82)$, relationships with colleagues $(\alpha=0.71)$, the relationship with the supervisor $(\alpha=0.82)$, information $(\alpha=0.86)$ and participation $(\alpha=0.88)$.

Perceived organisational support for strengths use and proactive behaviour towards strengths use: POSSU and PBSU were measured by means of the new questionnaire developed by Els et al. (in press). POSSU was measured by means of seven items (e.g. 'This organisation uses my strengths') and PBSU was measured by means of eight items (e.g. 'I use my strengths at work'). All the items were scored on a seven-point scale ranging from 0 (never) to 6 (almost always). Els et al. report a Cronbach's alpha coefficient of 0.96 for POSSU and 0.92 for PBSU.

Work engagement: Work engagement was measured by means of the Utrecht Work Engagement Scale (UWES) (Schaufeli et al., 2002). The UWES is scored on a seven-point frequency-rating scale, varying from 0 (never) to 6 (every day). Vigour was measured by means of four items (e.g. 'At my work, I feel I am bursting with energy'). Dedication was measured by means of four items (e.g. 'I am enthusiastic about my job'). The Cronbach's alpha coefficients range between 0.75 and 0.86 (Schaufeli et al., 2002). In a sample of 2396 members of the South African Police Service, Storm and Rothmann (2003) obtained sufficient Cronbach's alpha coefficients for vigour $(\alpha=0.78)$ and dedication $(\alpha=0.89)$.

\section{Research procedure and ethical considerations}

After permission was obtained from the management of the various occupational groups, a letter requesting their participation was emailed to the individuals who were to take part in the study. The letter explained the objectives and importance of the study. The questionnaire was then sent to different organisations and sectors in South Africa. The participants completed the questionnaires electronically or manually, being provided with an electronic questionnaire or manual booklet based on their need or preference. The questionnaire was completed by the different departments or clusters within the organisations. The time frame indicated for the completion of the questionnaire was approximately 40 minutes. The participants were given two to three weeks to return the questionnaires. They were reminded of its completion a week before the questionnaires 
were to be collected. Thereafter, the data analysis was performed. Participation in the study was voluntary, and the confidentiality and anonymity of the participants were emphasised. Organisations that requested feedback were given feedback on the results that were obtained.

\section{Statistical analysis}

The statistical analysis of this study was carried out using the SPSS program and Mplus 6.1 (Muthén \& Muthén, 2010). The rho coefficients (the proportion variance explained by the factor divided by the total variance; Wang \& Wang, 2012) were used to determine the reliability of the constructs that were measured, and effect sizes were used to determine the practical significance of the results (Steyn \& Swanepoel, 2008). Cut-off points of 0.30 (medium effect) and 0.50 (large effect) were set for the practical significance of the correlation coefficients (Cohen, 1988). The confidence interval level for statistical significance was set at a value of $95 \%(p \leq 0.05)$. The specification of continuous latent variables in this model investigation was conducted with Mplus. It is assumed by the popular maximum likelihood (ML) estimator that the observed variables are measured on a continuous scale. The covariance matrix represented the input type. The latent variables were created using individual items as indicators - no item parcelling methods were used (Bandalos \& Finney, 2001).

The goodness-of-fit of the models was tested using the traditional $\chi^{2}$ statistic, the comparative fit index (CFI), the Tucker-Lewis index (TLI), the root mean square error of approximation (RMSEA), and the standardised root mean square residual (SRMR). Even though there is limited agreement on the cut-off values for adequate fit (Lance, Butts \& Michels, 2006), general guidelines were followed for this study whereby fit was considered adequate if CFI and TLI values were larger than 0.90 (Byrne, 2010; Hoyle, 1995). An RMSEA value of 0.05 or less indicates a good fit, and values between 0.08 and 0.05 represent a moderately good model fit (Browne \& Cudeck, 1993). According to Hu and Bentler (1999), the SRMR value should be smaller than 0.05. The Akaike information criterion (AIC) and sample adjusted Bayesian information criterion (BIC) were used to compare the fit of competing models.

\section{Results}

To examine the validity of the measurement model, various models were systematically compared. Firstly, the hypothesised model (Model 1) was tested. This model was tested by creating eight latent variables, which included autonomy (five items), relationship with colleagues (three items), relationship with supervisors (four items), information (four items), participation (four items), POSSU (seven items), PBSU (seven items) and a one-factor work engagement variable (eight items). Items with poor factor loadings $(\leq 0.40)$ were omitted. The items were used as indicators of each latent variable in the measurement model. No errors were allowed to correlate.

In order to test whether alternative models might provide more plausible explanations for the observed inter-item covariance matrix, competing models were tested. Model 2 is similar to Model 1, but instead of a one-factor engagement model, a two-factor engagement model was tested (treating vigour and dedication separately). However, when this model was tested, the latent variables' covariance matrix was not positive definite. Therefore, in Model 3 and Model 4 work engagement was again tested as a one-factor model. In Model 3 , four latent variables were created: all five job resources were specified as one factor, engagement was specified as one factor, POSSU as one factor and PBSU as the final factor. Finally, Model 4 was specified with three latent variables: a one-factor job resources variable, a one-factor engagement variable and a one-factor strengths variable (where POSSU and PBSU loaded on one factor). The results are reported in Table 1.

As can be seen in Table 1, Model 1 had the lowest AIC and BIC values, indicating that this model fitted the data best $\left(\chi^{2}=1769.14 ; d f=791 ; p<0.05 ;\right.$ CFI = 0.91; TLI = 0.90; SRMR $=0.05 ;$ RMSEA $=0.06$ ). Model 1 therefore shows good model fit and can be considered a plausible explanation for the observed inter-item covariance matrix. The nonstandardised and standardised loadings, intercept and residual variances are shown in Table 2.

Table 3 shows the correlation statistics and descriptive statistics of the latent variables for Model 1. All means were zero because the latent variables were standardised.

As can be seen in Table 3, all relationships were positive. Autonomy, relationship with colleagues, relationship with supervisors and participation had statistically and practically significant (medium effect) relationships with engagement. Information had the highest correlation with engagement (0.50). POSSU had a statistically and practically significant (large effect) relationship with engagement, whilst PBSU had a statistically and practically significant (medium effect) relationship with engagement.

TABLE 1: Results for the different measurement models.

\begin{tabular}{|c|c|c|c|c|c|c|c|c|c|}
\hline Model & $\chi^{2}$ & $d f$ & $p$ & CFI & TLI & RMSEA & SRMR & AIC & BIC \\
\hline Model $1^{\text {a }}$ & 1769.141 & 791 & 0.00 & 0.91 & 0.90 & 0.06 & 0.05 & 44031.410 & 44644.936 \\
\hline Model $2^{b}$ & - & - & - & - & - & - & - & - & - \\
\hline Model $3^{c}$ & 3183.822 & 813 & 0.00 & 0.79 & 0.77 & 0.09 & 0.07 & 45402.091 & 45927.970 \\
\hline Model $4^{\mathrm{d}}$ & 3090.203 & 798 & 0.00 & 0.79 & 0.78 & 0.09 & 0.08 & 45338.471 & 45924.110 \\
\hline
\end{tabular}

$\chi^{2}$, chi-square; $d f$, degrees of freedom; $p$, statistical significance; CFI, comparative fit index; TLI, Tucker-Lewis index; RMSEA, root mean square error of approximation; SRMR, standardised root mean square residual; AIC, Akaike information criterion; BIC, Bayesian information criterion.

a, Five-factor job resources, one-factor engagement, two-factor strengths.

bive-factor job resources, two-factor engagement, two-factor strengths; covariance matrix was not positive definite.

', One-factor job resources, one-factor engagement, two-factor strengths.

', One-factor job resources, one-factor engagement, one-factor strengths. 
In order to test the hypothesised structural model (Model 1), direct paths were specified between job resources and work engagement (Hypothesis 1), POSSU and work engagement (Hypothesis 2) and PBSU and work engagement (Hypothesis 3). Competing models were tested where the paths were constrained to zero from both POSSU and PBSU (Model 2), only POSSU and only PBSU (Model 4). The results can be seen in Table 4 .

TABLE 2: Factor loadings, intercept and residual variances of the measurement model.

\begin{tabular}{|c|c|c|c|c|}
\hline Factor & $\begin{array}{l}\text { Non-standardised } \\
\text { loading }\end{array}$ & $\begin{array}{l}\text { Standardised } \\
\text { loading }\end{array}$ & Intercept & $\begin{array}{l}\text { Residual } \\
\text { variances }\end{array}$ \\
\hline \multicolumn{5}{|c|}{ Autonomy } \\
\hline Item 1 & 1.00 & 0.62 & 2.78 & 0.62 \\
\hline Item 2 & 1.03 & 0.72 & 3.08 & 0.48 \\
\hline Item 3 & 1.05 & 0.73 & 3.06 & 0.46 \\
\hline Item 4 & 0.97 & 0.69 & 3.47 & 0.53 \\
\hline Item 5 & 1.07 & 0.70 & 2.76 & 0.51 \\
\hline \multicolumn{5}{|c|}{ Relationship with colleagues } \\
\hline Item 1 & 1.00 & 0.43 & 3.50 & 0.82 \\
\hline Item 2 & 1.42 & 0.82 & 5.21 & 0.33 \\
\hline Item 3 & 1.62 & 0.87 & 4.83 & 0.24 \\
\hline \multicolumn{5}{|c|}{ Relationship with supervisor } \\
\hline Item 1 & 1.00 & 0.63 & 3.58 & 0.60 \\
\hline Item 2 & 1.17 & 0.80 & 3.94 & 0.36 \\
\hline Item 3 & 1.24 & 0.72 & 2.85 & 0.49 \\
\hline Item 4 & 1.23 & 0.80 & 3.68 & 0.36 \\
\hline \multicolumn{5}{|c|}{ Information } \\
\hline Item 1 & 1.00 & 0.76 & 3.14 & 0.42 \\
\hline Item 2 & 1.13 & 0.84 & 3.06 & 0.30 \\
\hline Item 3 & 1.19 & 0.86 & 2.86 & 0.27 \\
\hline Item 4 & 1.07 & 0.75 & 2.72 & 0.44 \\
\hline \multicolumn{5}{|c|}{ Participation } \\
\hline Item 1 & 1.00 & 0.84 & 2.72 & 0.44 \\
\hline Item 2 & 0.99 & 0.79 & 3.01 & 0.29 \\
\hline Item 3 & 0.99 & 0.75 & 2.69 & 0.38 \\
\hline Item 4 & 0.96 & 0.75 & 2.65 & 0.43 \\
\hline \multicolumn{5}{|c|}{ Perceived organisational support for strengths use } \\
\hline Item 1 & 1.00 & 0.76 & 2.80 & 0.43 \\
\hline Item 2 & 1.23 & 0.84 & 2.47 & 0.29 \\
\hline Item 3 & 1.33 & 0.88 & 2.32 & 0.23 \\
\hline Item 4 & 1.33 & 0.91 & 2.33 & 0.18 \\
\hline Item 5 & 1.41 & 0.93 & 2.18 & 0.14 \\
\hline Item 6 & 1.34 & 0.91 & 2.27 & 0.18 \\
\hline Item 7 & 1.32 & 0.89 & 2.25 & 0.21 \\
\hline \multicolumn{5}{|c|}{ Employees' proactive behaviour towards strengths use } \\
\hline Item 3 & 1.00 & 0.76 & 3.56 & 0.42 \\
\hline Item 4 & 1.19 & 0.81 & 3.01 & 0.35 \\
\hline Item 5 & 1.15 & 0.79 & 3.01 & 0.37 \\
\hline Item 6 & 1.13 & 0.76 & 2.96 & 0.43 \\
\hline Item 7 & 1.21 & 0.86 & 3.23 & 0.25 \\
\hline Item 8 & 1.21 & 0.86 & 3.18 & 0.26 \\
\hline Item 9 & 1.03 & 0.75 & 3.38 & 0.43 \\
\hline \multicolumn{5}{|c|}{ Engagement } \\
\hline Item 1 & 1.00 & 0.76 & 1.87 & 0.77 \\
\hline Item 2 & 1.01 & 0.81 & 2.50 & 0.43 \\
\hline Item 3 & 1.15 & 0.83 & 2.40 & 0.47 \\
\hline Item 4 & 0.79 & 0.67 & 2.67 & 0.35 \\
\hline Item 5 & 0.73 & 0.48 & 2.20 & 0.32 \\
\hline Item 6 & 0.95 & 0.73 & 2.30 & 0.40 \\
\hline Item 7 & 1.07 & 0.78 & 3.08 & 0.56 \\
\hline Item 8 & 0.80 & 0.64 & 2.76 & 0.59 \\
\hline
\end{tabular}

The estimates and significance of the direct structural paths in the model are indicated in Table 5.

With regard to the paths investigated in Hypothesis 1, the results indicate that there was only one significant relationship between job resources and work engagement - that of relationship with supervisors and work engagement $(\beta=0.21 ; p=0.01)$. This provides partial support for Hypothesis 1 . The results show that there were significant positive relationships between POSSU and work engagement $(\beta=0.22 ; p=0.00)$ and between PBSU and work engagement $(\beta=0.22 ; p=0.00)$, which provides support for Hypothesis 2 and Hypothesis 3.

\section{Discussion Outline of the results}

The aim of this study was to test a structural model of job resources, perceived organisational support for strengths use, proactive behaviour towards strengths use and work engagement amongst South African employees. The relationship between these specific variables has never been tested in the South African context. The hypotheses were based on the broaden-and-build theory.

Hypothesis 1 stated that job resources have a significant positive relationship with work engagement. Based on the assumptions of the JD-R model, it was argued that employees will be more engaged in their work if they are provided with job resources to help them decrease the demands of their work, because of the motivational role that job resources fulfil (Bakker \& Demerouti, 2008; Demerouti \& Bakker, 2011). The results indicated that only one job resource was related to work engagement: the relationship between employee and supervisor. This result shows that employees are more engaged in their work when they have a positive relationship with their supervisors, which will most likely motivate them to achieve their work goals, leading to better work performance (Bakker et al., 2008). This is in concurrence with several previous research studies that also found a significant relationship between having a positive relationship with one's supervisor and increased work engagement (Bakker \& Demerouti, 2007; Hakanen, Bakker \& Schaufeli, 2006) and ultimately increased overall performance (Bakker \& Demerouti, 2008). No significant relationships were found between the other job resources that were included in the study and work engagement. These findings were unexpected, since they were not concurrent with previous studies that found significant relationships between autonomy (Bakker \& Demerouti, 2008), relationship with colleagues (Bakker \& Demerouti, 2008), information (Bakker et al., 2008) and participation (Bakker, Van Veldhoven \& Xanthopoulou, 2010). Hypothesis 1 was therefore partially accepted.

The unique contribution of this research is that, for the first time, both organisational and employees' strengths use were included in a structural model to determine whether they 
TABLE 3: Correlation matrix ( $r$ ) and descriptive statistics of the latent variables.

\begin{tabular}{|c|c|c|c|c|c|c|c|c|c|}
\hline Variable name & SD & $\rho$ & 1 & 2 & 3 & 4 & 5 & 6 & 7 \\
\hline 1. Autonomy & 0.64 & 0.64 & - & - & - & - & - & - & - \\
\hline 2. Relationship with colleagues & 0.39 & 0.70 & 0.28 & - & - & - & - & - & - \\
\hline 3. Relationship with supervisors & 0.57 & 0.73 & 0.39 & 0.53 & - & - & - & - & - \\
\hline 4. Information & 0.70 & 0.83 & 0.41 & 0.28 & 0.58 & - & - & - & - \\
\hline 5. Participation & 0.76 & 0.80 & 0.67 & 0.16 & 0.48 & 0.59 & - & - & - \\
\hline 6. Perceived organisational support for strengths use & 1.14 & 0.93 & 0.46 & 0.22 & 0.45 & 0.57 & 0.57 & - & - \\
\hline 7. Employees' proactive behaviour towards strengths use & 1.02 & 0.83 & 0.36 & 0.23 & 0.28 & 0.47 & 0.42 & 0.53 & - \\
\hline 8. Engagement & 1.39 & 0.68 & 0.36 & 0.32 & 0.49 & 0.50 & 0.41 & 0.53 & 0.48 \\
\hline
\end{tabular}

$\mathrm{SD}$, standard deviation.

$r \geq 0.30$ is practically significant (medium effect); $r \geq 0.50$ is practically significant (large effect).

$p \leq 0.01$ for all values.

TABLE 4: Results for the structural model.

\begin{tabular}{|c|c|c|c|c|c|c|c|c|c|}
\hline Model & $\chi^{2}$ & $d f$ & $p$ & CFI & TLI & RMSEA & SRMR & AIC & BIC \\
\hline Model $1^{\mathrm{a}}$ & 1769.14 & 791 & 0.00 & 0.91 & 0.90 & 0.06 & 0.05 & 44031.410 & 44644.936 \\
\hline Model $2^{b}$ & 1808.57 & 793 & 0.00 & 0.91 & 0.90 & 0.06 & 0.06 & 44066.841 & 44672.399 \\
\hline Model $3^{c}$ & 1781.83 & 792 & 0.00 & 0.91 & 0.90 & 0.06 & 0.05 & 44042.099 & 44651.642 \\
\hline Model $4^{d}$ & 1784.03 & 792 & 0.00 & 0.91 & 0.90 & 0.06 & 0.05 & 44044.302 & 44653.844 \\
\hline
\end{tabular}

$\chi^{2}$, chi-square; $d f$, degrees of freedom; $p$, statistical significance; CFI, comparative fit index; TLI, Tucker-Lewis index; RMSEA, root mean square error of approximation; SRMR, standardised root mean square residual; AIC, Akaike information criterion; BIC, Bayesian information criterion.

a, All the variables are included

Only job resources are included; POSSU (Perceived organisational support for strengths use) and PBSU (Proactive behaviour towards strengths use) are constraint.

, Job resources and PBSU are included, POSSU is constraint.

d, Job resources and POSSU are included, PBSU is constraint.

TABLE 5: Estimates $(\beta)$ of the direct structural paths in the standardised model.

\begin{tabular}{|c|c|c|c|c|}
\hline Structural path & Non-standard beta & Standard beta & SE (Non-standard) & $p$ \\
\hline Engagement $\rightarrow$ Autonomy & 0.11 & 0.05 & 0.15 & 0.48 \\
\hline Engagement $\rightarrow$ Relationship with colleagues & 0.22 & 0.06 & 0.21 & 0.31 \\
\hline Engagement $\rightarrow$ Relationship with supervisors & 0.50 & 0.21 & 0.18 & $0.01 *$ \\
\hline Engagement $\rightarrow$ Information & 0.23 & 0.12 & 0.14 & 0.09 \\
\hline Engagement $\rightarrow$ Participation & -0.05 & -0.03 & 0.15 & 0.75 \\
\hline Engagement $\rightarrow$ POSSU & 0.26 & 0.22 & 0.08 & $0.00^{*}$ \\
\hline Engagement $\rightarrow$ PBSU & 0.29 & 0.22 & 0.08 & $0.00^{*}$ \\
\hline
\end{tabular}

$\beta$, beta; SE, standard error; $p$, obtained significance value; POSSU, perceived organisational support for strengths use; PBSU, proactive behaviour towards strengths use. $*, p \leq 0.05$

have a relationship with work engagement. Hypothesis 2 stated that there is a significant positive relationship between POSSU and work engagement and Hypothesis 3 stated that there is a significant positive relationship between PBSU and work engagement. The results supported both these hypotheses.

It was argued that POSSU is a job resource that fulfils an extrinsic motivational role at a macro level. This reasoning was based on the JD-R model's definition of a job resource (Demerouti \& Bakker, 2011; Schaufeli \& Bakker, 2004) and on the motivational nature of job resources (Bakker \& Demerouti, 2007). Organisations that show support for employees in using their strengths may foster the willingness of employees to dedicate their efforts and abilities to the task at hand (Demerouti \& Bakker, 2011). The significant relationship between POSSU and work engagement was also confirmed by a previous study by Linley and Harrington (2006), who found that an organisational focus on strengths use will lead to higher energy and engagement levels, more motivation and higher performance. This finding expands the literature on the JD-R model by confirming that POSSU as a job resource is positively related to engagement (which is in accordance with several studies providing evidence that job resources are linked to work engagement, e.g. Bakker
\& Demerouti, 2007, 2008; Mostert, 2006; Mostert et al., 2011; Schaufeli \& Bakker, 2004). Therefore, adopting a strengths approach by providing support to employees in using their strengths allows employees to engage in what they do best. Wood et al. (2011) reported that strengths use leads to wellbeing over time. If support for strengths use naturally leads to work engagement, organisations may focus interventions in such a way that they build long-term work engagement and optimal functioning.

Employees' PBSU also had a significant relationship with work engagement. This finding supports the theoretical notions that have been put forward for strengths by several researchers (e.g. Clifton \& Anderson, 2002; Peterson \& Seligman, 2004), who argue that individuals have an intrinsic motivation to apply their strengths. When they do so, they could experience authenticity, vitality and well-being. Park, Peterson and Seligman (2004) also argue that when people are playing to their strengths, it improves well-being because they are doing what they naturally do best. This generates feelings of autonomy, competence, confidence, and self-esteem. When employees proactively use their own strengths, it can also create energy and enhance dedication, because they behave according to their own flow, rather than struggling upriver against the currents of their natural capacities (Clifton \& Harter, 2003). 
These findings are also in line with the views of human nature proposed by Karen Horney (1951) and Carl Rogers (1963), amongst many others (including Aristotle and Jung: see Joseph \& Linley, 2005). Horney and Rogers proposed that people have within them socially constructive and directional tendencies that guide them in realising their potential, that is, playing to their strengths. Both Horney and Rogers believed that people yearn to express and activate themselves. When they are able to do so, they are more authentic and as a result achieve higher levels of well-being. This can possibly be used to explain why PBSU is linked with work engagement. When employees are proactive in using and applying their own strengths in the workplace, they feel good about themselves, are better able to achieve things and are working towards fulfilling their potential (Linley \& Harrington, 2006).

It was interesting to note that the relationships POSSU and PBSU had with work engagement were of equal strength. Although both models - where first POSSU and then PBSU was constrained - were significantly associated with work engagement, the model that fitted the data best was the model where both POSSU and PBSU were included. This implies that both the individual and the organisation should work together using employees' strengths in order to promote work engagement. It is therefore possible that, according to the broaden-and-build theory of positive emotions, the support of strengths use by the organisation as well as the proactive behaviour towards the strengths use of employees create positive emotions that broaden peoples' thoughtaction repertoires and build their personal resources. This helps employees to become more creative, knowledgeable and resilient, which in turn is associated with more work engagement.

\section{Practical implications}

Organisations will not be able to attain and keep their competitive advantage by merely focusing on developing their employees' weaknesses (Luthans \& Youssef, 2007). It is of vital importance that organisations use employees' strengths, but also that employees show more proactive behaviour towards using their own strengths. Together with job resources, POSSU and PBSU will lead to happier and more engaged employees working towards goal achievement.

The results indicate that if organisations provide their employees with sufficient job resources, such as supervisory support and support for strengths use, it could be associated with their work engagement levels. Job resources will not only assist the employees in handling high job demands, but will most likely be associated with self-starting behaviour. This will not only be beneficial to the employees themselves, but also to the organisation. Employees who are engaged in their work experience good health and a positive work affect (Demerouti et al., 2001; Rothbard, 2001). Harter et al. (2002) also reported that employees' engagement levels have a positive impact on the performance of the organisation's business units (i.e. higher organisational profitability, enhanced productivity, more customer satisfaction and loyalty, lower employee turnover and improved safety).

\section{Limitations and recommendations}

It is important to note certain limitations of this study. The first limitation is that a cross-sectional research approach was followed, which does not allow for the measurement of variables that change over time. Therefore, the relationships that existed between the different variables were interpreted, and not established. It is therefore recommended that future research should include longitudinal studies in order to evaluate the longer-term outcomes and the relationships between job resources, POSSU and PBSU and work engagement.

The second limitation is that self-report questionnaires were used to obtain the data. This could have increased the problem of having to deal with common method variance. This means that self-report questionnaires are biased in nature, and could therefore have influenced the results that were obtained. However, there are few alternative methods available that can be used to deal with the problem of selfreport questionnaires. It is recommended that future research studies make use of measurement methods that are more objective.

The third limitation is that this study only focused on the positive aspects in the field of psychology. According to Peterson and Seligman (2003), the positive psychology movement's aim is to correct the imbalance that occurred due to only focusing on the negative aspects. Even though the positive psychology movement only made its appearance in recent years and the literature on the positive aspects is still relatively limited, it is important to also take the negative aspects (e.g. job demands, following exclusively a deficiencybased approach, burnout) into consideration in order to ensure that a balance is kept. It is therefore recommended that future research studies should also include other variables, such as those indicated above, when testing a structural model.

The sample group included several occupational groups in different industries, as well as different genders, marital statuses, ages and racial groups. However, the fourth possible limitation is that the participants were required to have at least a Grade 12 qualification and, if not, a good understanding of the English language. Furthermore, they had to be part of South Africa's workforce. This means that the results cannot be generalised to all South African employees. Additionally, English may have been the respondents' second or even third language, which increased the chances of the participants not understanding the questions correctly. It is recommended that future research consider these factors and not limit their sample group to language or qualification factors.

Even though this study delivered interesting and meaningful results, it should be noted that certain limitations may be overcome by future research studies. It is recommended that future studies employ a longitudinal design. A longitudinal design will assist in determining the positive outcomes of job resources, POSSU and PBSU with regard to employees' work engagement over a long period. 
It is further recommended that future research consider the fact that the newly developed instrument that was used to measure POSSU and PBSU is only available in English. South Africa has 11 official languages and English is a second or even third language for many people. It is therefore recommended that future research adapt this questionnaire to be used by other language groups in the South African context.

\section{Conclusions}

Taken together, this research on perceived organisational support for strengths use and employees' proactive behaviour towards using their own strengths, and the relationship thereof with work engagement, suggests that the use of strengths is more than a passing fad. POSSU and PBSU could be potentially important tools in personal and organisational development. The combination of organisational and individual approaches towards using strengths explained a substantial proportion of variance in work engagement. The findings therefore demonstrate that POSSU and PBSU are both important and independent factors that are associated with work engagement. This is the first empirical research to link the use of strengths from both an organisational and an individual perspective to engagement specifically in the workplace. This provides an important, but preliminary, basis for adding to the development of work engagement interventions.

\section{Acknowledgements}

This research was conducted as part of the first author's master's degree, completed at the North-West University (Potchefstroom Campus), South Africa.

Thank you to Ian Rothmann Jr for his assistance with the statistical analysis.

\section{Competing interests}

The material described in this article is based on work that was supported by the National Research Foundation (NRF). Any opinion, findings and conclusions or recommendations expressed in this material are those of the authors and therefore the NRF does not accept any liability in regard thereto.

\section{Authors' contributions}

C.B. (North-West University) wrote the manuscript as part of her master's dissertation. She also assisted in the experimental and project design. K.M. (North-West University) was the project leader and was responsible for the experimental and project design and supervision; she also assisted in the writing of the article and with the statistical analysis and interpretation of the results.

\section{References}

Bakker, A.B., \& Demerouti, E. (2007). The job demands-resources model: State of the art. Journal of Managerial Psychology, 22, 309-328. http://dx.doi. org/10.1108/02683940710733115
Bakker, A.B., \& Demerouti, E. (2008). Towards a model of work engagement. Career Development International, 13(3), 209-223. http://dx.doi. org/10.1108/13620430810870476

Bakker, A.B., Demerouti, E., Taris, T.W., Schaufeli, W.B., \& Schreurs, P.J.G. (2003). A multigroup analysis of the job demands-resources model in four home care organizations. International Journal of Stress Management, 10(1), 16-38. http:// dx.doi.org/10.1037/1072-5245.10.1.16

Bakker, A.B., Demerouti, E., \& Verbeke, W. (2004). Using the job demands-resources model to predict burnout and performance. Human Resource Management, 43(1), 83-104. http://dx.doi.org/10.1002/hrm.20004

Bakker, A.B., Hakanen, J.J., Demerouti, E., \& Xanthopoulou, D. (2007). Job resources boost work engagement, particularly when job demands are high. Journal of Educational Psychology, 99(2), 274-284. http://dx.doi.org/10.1037/0022 0663.99.2.274

Bakker, A.B., Schaufeli, W.B., Leiter, M.P., \& Taris, T.W. (2008). Work engagement: An emerging concept in occupational health psychology. Work \& Stress, 22(3), 187200. http://dx.doi.org/10.1080/02678370802393649

Bakker, A.B., Van Veldhoven, M., \& Xanthopoulou, D. (2010). Beyond the demandcontrol model: Thriving on high job demands and resources. Journal of Personne Psychology, 9(1), 3-16. http://dx.doi.org/10.1027/1866-5888/a000006

Bandalos, D.L., \& Finney, S.J. (2001). Item parcelling issues in structural equation modelling. In: G.A. Marcoulides \& R.E. Schumaker (Eds.), New developments and techniques in structural equation modelling (pp. 269-296). Mahwah, NJ: Lawrence Erlbaum Associates, Inc.

Biswas-Diener, R., Kashdan, T.B., \& Minhas, G. (2011). A dynamic approach to psychological strength development and intervention. The Journal of Positive Psychology, 6(2), 106-118. http://dx.doi.org/10.1080/17439760.2010.545429

Browne, M.W., \& Cudeck, R. (1993). Alternative ways of assessing model fit. In K.A Bollen, \& J.S. Long (Eds.), Testing structural equation models (pp. 136-162). Newbury Park, CA: Sage.

Buckingham, M., \& Clifton, D.O. (2001). Now, discover your strengths. New York: Free Press.

Byrne, B.M. (2010). Structural equation modelling with AMOS. (2nd edn.). New York: Taylor \& Francis Group.

Clifton, D.O. \& Anderson, E. (2002). StrengthsQuest: Discover and develop your strengths in academics, career, and beyond. Washington, DC: The Gallup Organization

Clifton, D.O., \& Harter, J.K. (2003). Investing in strengths. In A.K.S. Cameron, B.J.E. Dutton, \& C.R.E. Quinn (Eds.), Positive organizational scholarship (pp. 111-121) San Francisco: Berrett-Koehler Publishers Inc.

Cohen, J. (1988). Statistical power analysis for the behavioral sciences. Orlando: Academic Press. http://dx.doi.org/10.1002/bs.3830330104

Crant, J.M. (2000). Proactive behavior in organizations. Journal of Management 26(3), 435-462. http://dx.doi.org/10.1177/014920630002600304

Demerouti, E., \& Bakker, A.B. (2011). The job demands-resources model: Challenges for future research. South African Journal of Industrial Psychology 37(2), 1-9.

Demerouti, E., Bakker, A.B., De Jonge, J., Janssen, P.P.M., \& Schaufeli, W.B. (2001) Burnout and engagement at work as a function of demands and control. Scandinavian Journal of Work Environment and Health, 27, 279-286. http:// dx.doi.org/10.5271/sjweh.615

Duckworth, A.L., Steen, T.A., \& Seligman, M.E.P. (2005). Positive psychology in clinical practice. Clinical Psychology Review, 1, 629-651. http://dx.doi.org/10.1146/ annurev.clinpsy.1.102803.144154

Eisenberger, R., Huntington, R., Hutchison, S., \& Sowa, D. (1986). Perceived organizational support. Journal of Applied Psychology, 71(3), 500-507. http:// dx.doi.org/10.1037/0021-9010.71.3.500

Els, C., Mostert, K., Van Woerkom, M., Rothmann, S. Jr, \& Bakker, A.B. (in press). The development of a strengths use and deficit improvement questionnaire. Journal of Managerial Psychology.

Estrada, C.A., Isen, A.M., \& Young, M.J. (1997). Positive affect facilitates integration of information and decreases anchoring in reasoning among physicians. Organizational Behavior and Human Decision Process, 72, 117-135. http://dx.doi. org/10.1006/obhd.1997.2734

Fredrickson, B.L. (1998). What good are positive emotions? Review of General Psychology, 2, 300-319. http://dx.doi.org/10.1037/1089-2680.2.3.300

Fredrickson, B.L. (2001). The role of positive emotions in positive psychology: The broaden-and-build theory of positive emotions. American Psychologist, 56, 218226. http://dx.doi.org/10.1037/0003-066X.56.3.218

Fredrickson, B.L. (2004). The broaden-and-build theory of positive emotions. The Royal Society, 359, 1367-1377.

Fredrickson, B.L., Brown, S., Cohn, M.A., Conway, A., \& Mikels, J. (2005, January) Positive emotions build personal resources and predict future subjective wellbeing. Paper presented at the Sixth Annual Meeting of the Society for Personality and Social Psychology, New Orleans, LA.

Fredrickson, B.L., \& Joiner, T. (2002). Positive emotions trigger upward spirals toward emotional well-being. Psychological Science, 13, 172-175. http://dx.doi. org/10.1111/1467-9280.00431

Fredrickson, B.L., \& Losada, M.F. (2005). Positive affect and the complex dynamics of human flourishing. American Psychologist, 60(7), 678-686. http://dx.doi. org/10.1037/0003-066X.60.7.678

Frese, M., \& Fay, D. (2001). Personal initiative: An active performance concept for work in the 21st century. Research in Organizational Behavior, 23(4), 133-187. $\mathrm{http}: / / \mathrm{dx}$.doi.org/10.1016/S0191-3085(01)23005-6 
Frese, M., Kring, W., Soose, A., \& Zempel, J. (1996). Personal initiative at work: Differences between East and West Germany. Academy of Management Journal, 39(1), 37-63. http://dx.doi.org/10.2307/256630

Govindji, R., \& Linley, P.A. (2007). Strengths use, self-concordance and well-being Implications for strengths coaching and coaching psychologists. International Coaching Psychology Review, 2(2), 143-153.

Hakanen, J., Bakker, A.B., \& Schaufeli, W.B. (2006). Burnout and work engagement among teachers. The Journal of School Psychology, 43, 495-513. http://dx.doi. org/10.1016/j.jsp.2005.11.001

Harter, J.K., Schmidt, F.L., \& Hayes, T.L. (2002). Business-unit-level relationship between employee satisfaction, employee engagement, and business outcomes: A meta-analysis. Journal of Applied Psychology, 87, 268-279. http://dx.doi. org/10.1037/0021-9010.87.2.268

Henkin, A.B., \& Holliman, S.L. (2009). Urban teacher commitment exploring associations with organizational conflict, support for innovation, and participation Urban Education, 44(2), 160-180. http://dx.doi.org/10.1177/0042085907312548

Horney, K. (1951). Neurosis and human growth: The struggle toward self-realization. London: Routledge \& Kegan Paul.

Hoyle, R.H. (1995). The structural equation modelling approach: Basic concepts and fundamental issues. In R.H. Hoyle (Ed.), Structural equation modelling: concepts, issues, and applications (pp. 1-15). Thousand Oaks, CA: Sage.

Hu, L.T., \& Bentler, P.M. (1999). Cut-off criteria for fit indexes in covariance structure analysis: Conventional criteria versus new alternatives. Structural Equation Modeling, 6 (1), 1-55. http://dx.doi.org/10.1080/10705519909540118

Hung, H., \& Mondejar, R. (2001). An investigation into the inter-relationship among work, family and part-time education in Hong Kong. Journal of Vocational Educatio and Training, 53(4), 561-576. http://dx.doi.org/10.1080/13636820100200177

Jimerson, S.R., Sharkey, J.D., Nyborg, V., \& Furlong, M.J. (2004). Strength-based assessment and school psychology: A summary and thesis. The California Schoo Psychologist, 9, 9-19.

Joseph, S. \& Linley, P.A. (2005). Positive adjustment to threatening events: An organismic valuing theory of growth through adversity. Review of General Psychology, 9, 262-280. http://dx.doi.org/10.1037/1089-2680.9.3.262

Kristjánsson, K. (2010). Positive psychology, happiness, and virtue: The troublesome conceptual issues. Review of General Psychology, 14(4), 296-310. http://dx.doi. org/10.1037/a0020781

Lance, C.E., Butts, M.M., \& Michels, L.C. (2006). The sources of four commonly reported cut-off criteria: What did they really say? Organizational Research Methods, 9, 202-221. http://dx.doi.org/10.1177/1094428105284919

Liehmann, L. (2009). How to build a strength-based organization: Learnings from Craigwood Youth Services. Unpublished doctoral thesis, Benedictine University, East Eisenhower, Chicago, IL, USA.

Linley, P.A., \& Harrington, S. (2005). Positive psychology and coaching psychology: Perspectives on integration. The Coaching Psychologist, 1(1), 13-14.

Linley, P.A., \& Harrington, S. (2006). Strengths coaching: A potential-guided approach to coaching psychology. International Coaching Psychology Review, 1(1), 37-46.

Linley, P.A., Nielsen, K.M., Wood, A.M., Gillett, R., \& Biswas-Diener, R. (2010). Using signature strengths in pursuit of goals: Effects on goal progress, need satisfaction and well-being, and implications for coaching psychologists. Internationa Coaching Psychology Review, 5(1), 8-17.

Littman-Ovadia, H., \& Steger, M.F. (2010). Character strengths and well-being among volunteers and employees: Toward an integrative model. The Journal of Positive Psychology, 5, 419-430. http://dx.doi.org/10.1080/17439760.2010.516765

Luthans, F. (2002a). The need for and meaning of positive organizational behaviour. Journal of Organizational Behavior, 23, 695-706. http://dx.doi.org/10.1002/ journal 165

Luthans, F. (2002b). Positive organisational behaviour: Developing and managing psychological strengths. Academy of Management Executive, 16(1), 57-75. http://dx.doi.org/10.5465/AME.2002.6640181

Luthans, F., \& Youssef, C.M. (2007). Emerging positive organizational behaviour. Journal of Management, 33(3), 321-349. http://dx.doi.org/10.1177/0149206307300814

Madjar, N., Oldham, G.R., \& Pratt, M. G. (2002). There's no place like home? The contributions of work and non-work creativity support to employee's creative
performance. Academy of Management Journal, 45, 757-767. http://dx.doi. performance. Academ
org/10.2307/3069309

Martin, L.L., Ward, D.W., Achee, J.W., \& Wyer, R.S. (1993). Mood as input: People have to interpret the motivational implications of their moods. Journal of Personality and Social Psychology, 64, 317-326. http://dx.doi.org/10.1037/00223514.64.3.317

Morrison, E.W. (1993). Longitudinal study of the effects of information seeking on newcomer socialization. Journal of Applied Psychology, 78(2), 173-183. http:// dx.doi.org/10.1037/0021-9010.78.2.173

Morrison, E.W., \& Phelps, C.C. (1999). Taking charge at work: Extrarole efforts to initiate workplace change. Academy of Management Journal, 42(4), 403-419. $\mathrm{http}: / / \mathrm{dx}$.doi.org/10.2307/257011

Mostert, K. (2006). Work-home interaction as partial mediator between job resources and work engagement. Southern African Business Review, 10(2), 53-74.

Mostert, K., Peeters, M., \& Rost, I. (2011). Work-home interference and the relationship with job characteristics and well-being: A South African study among employees in the construction industry. Retrieved July 13, 2011 from http://www. wileyonlinelibrary.com

Muthén, L.K., \& Muthén, B.O. (2010). Mplus user's guide. (6th edn.). Los Angeles: Muthén \& Muthén.

Park, N., Peterson, C., \& Seligman, M.E.P. (2004). Strengths of character and wellbeing. Journal of Social and Clinical Psychology, 23, 603-619. http://dx.doi. org/10.1521/jscp.23.5.603.50748
Parker, S.K. (2000). From passive to proactive motivation: The importance of flexible role orientations and role breadth self-efficacy. Applied Psychology: An International Review, 49(3), 447-469. http://dx.doi.org/10.1111/1464An Internatior

Peterson, C.M., \& Seligman, M.E.P. (2003). Positive organizational studies: Lessons from positive psychology. In A.K.S. Cameron, B.J.E. Dutton, \& C.R.E. Quinn (Eds.), Positive organisational scholarship (pp. 14-31). San Francisco: Berret-Koehler Publishers, Inc. http://dx.doi.org/10.1177/1059601103028002002

Peterson, C., \& Seligman, M.E.P. (2004). Character strengths and virtues: A handbook and classification. New York: Oxford University Press. http://dx.doi.org/10.1093/ oxfordhb/9780195335446.013.0018

Peterson, C., Stephens, J.P., Park, N., Lee, F., \& Seligman, M.E.P. (2009). Strengths of character and work. In P.A. Linley, S. Harrington, \& N. Garcea (Eds.), Oxford handbook of positive psychology and work (pp. 221-234). Oxford: Oxford University Press.

Proctor, C., Maltby, J., \& Linley, P.A. (2009). Strengths use as a predictor of well-being and health-related quality of life. Journal of Happiness Studies, 10, 583-630. http://dx.doi.org/10.1007/s10902-008-9110-9

Proctor, C., Maltby, J., \& Linley, P.A. (2011). Strengths use as a predictor of well-being and health-related quality of life. Journal of Happiness Studies, 12, 153-169. http://dx.doi.org/10.1007/s10902-009-9181-2

Rhoades, L., \& Eisenberger, R. (2002). Perceived organizational support: A review of the literature. Journal of Applied Psychology, 87(4), 698-714. http://dx.doi. org/10.1037/0021-9010.87.4.698

Rogers, C.R. (1963). The actualizing tendency in relation to 'motives' and to consciousness. In M.R. Jones (Ed.), Nebraska symposium on motivation (Vol. 11, pp.1-24). Lincoln, NE: University of Nebraska Press.

Rothbard, N.P. (2001). Enriching or depleting? The dynamics of engagement in work and family roles. Administrative Science Quarterly, 46, 655-684. http://dx.doi. org/10.2307/3094827

Salkind, N.J. (2009). Exploring research. (7th edn.). New Jersey: Pearson Prentice Hall.

Schaufeli, W.B., \& Bakker, A.B. (2004). Job demands, job resources, and their relationship with burnout and engagement: A multi-sample study. Journal of Organizational Behavior, 25, 293-315. http://dx.doi.org/10.1002/job.248

Schaufeli, W.B., Salanova, M., González-Romá, V., \& Bakker, A.B. (2002). The measurement of engagement and burnout: $A$ two sample confirmatory factor analytic approach. Journal of Happiness Studies, 3, 71-92.

Seligman, M.E.P. (2002). Authentic happiness: Using the new positive psychology to realize your potential for lasting fulfillment. New York: The Free Press.

Seligman, M.E.P. (2011). Flourish: A visionary new understanding of happiness and well-being. New York: The Free Press.

Seligman, M.E.P., \& Csikszentmihalyi, M. (2000). Positive psychology: An introduction American Psychologist, 55(1), 5-14. http://dx.doi.org/10.1037/0003-066X.55.1.5

Seligman, M.E.P., Rashid, T., \& Parks, A.C. (2006). Positive psychotherapy. American Psychologist, 61, 774-788. http://dx.doi.org/10.1037/0003-066X.61.8.774

Seligman, M.E.P., Steen, T.A., Parks, N., \& Peterson, C. (2005). Positive psychology progress: Empirical validation of interventions. American Psychologist, 60(5), progress: Empirical validation of interventions. Americ

Shults, C. (2008). Making the case for a positive approach to improving organizational performance in higher education institutions. Community College Review, 36(2), 133-159. http://dx.doi.org/10.1177/0091552108324656

Sonnentag, S. (2003). Recovery, work engagement, and proactive behaviour: A new look at the interface between nonwork and work. Journal of Applied Psychology, 3, 518-528. http://dx.doi.org/10.1037/0021-9010.88.3.518

SPSS 18.0 for Windows [Computer software] (2009). Chicago: SPSS Inc.

Steyn, H.S., \& Swanepoel, C.J. (2008). Praktiese statistiek. (2nd edn.). Potchefstroom: Noordwes-Universiteit.

Storm, K., \& Rothmann, S. (2003). A psychometric analysis of the Utrecht Work Engagement Scale in the South African police service. South African Journal of Industrial Psychology, 29(4), 62-70.

Van Veldhoven, M., Meijman, T.F., Broersen, J.P.J., \& Fortuin, R.J. (1997). Handleiding VBBA: Onderzoek naar de beleving van psychosociale arbeidsbelasting en werkstress met behulp van de vragenlijst beleving en beoordeling van de arbeid [Manual VBBA: Research on the experience of psychosocial workload and job stress by means of the Questionnaire on the Experience and Evaluation of Work]. Amsterdam: SKB.

Van Veldhoven, M., Meijman, T.F., Broersen, J.P.J., \& Fortuin, R.J. (2002). Handleiding VBBA. (2nd edn.). Amsterdam: SKB Vragenlijstservices.

Wang, J., \& Wang, X. (2012) Structural equation modeling: Applications using Mplus. Chichester: Wiley. http://dx.doi.org/10.1002/9781118356258

Wood, A.M., Linley, P.A., Maltby, J., Kashdan, T.B., \& Hurling, R. (2011). Using personal and psychological strengths leads to increases in well-being over time: A longitudinal study and the development of the strengths use questionnaire. Personality and Individual Differences, 50, 15-19. http://dx.doi.org/10.1016/j. paid.2010.08.004

Xanthopoulou, D., Bakker, A.B., Demerouti, E., \& Schaufeli, W.B. (2009). Reciprocal relationships between job resources, personal resources, and work engagement. Journal of Vocational Behavior, 74, 235-244. http://dx.doi.org/10.1016/j. jvb.2008.11.003

Zelenski, J.M., Murphy, S.A., \& Jenkins, D.A. (2008). The happy-productive worker thesis revisited. Journal of Happiness Studies, 9, 521-537. http://dx.doi. org/10.1007/s10902-008-9087-4

Zhou, J., \& George, J.M. (2001). When job dissatisfaction leads to creativity: Encouraging the expression of voice. Academy of Management Journal, 44(4). 682-696. http://dx.doi.org/10.2307/3069410 